\title{
MEDIA PEMBELAJARAN STRUKTUR KONTROL PERULANGAN BERBASIS ANIMASI PADA MATA PELAJARAN PEMROGRAMAN DASAR
}

\author{
Anisa Rahmayanti, Cecep Riki \\ Pendidikan Teknologi Informasi FKIP Universitas Muhammadiyah Tasikmalaya \\ Email : $\underline{\text { rahyaanisa10@gmail.com }}$
}

\begin{abstract}
Abstraksi
Tujuan penelitian ini adalah untuk mengembangkan media pembelajaran berbasis animasi dengan Adobe Flash Cs6 agar dapat menampilkan animasi materi struktur kontrol perulangan. Metode yang digunakan dalam penelitian ini adalah Research and Development $(R \& D)$ dengan model pengembangan ADDIE (Analysis, Design, Development, Implementation, Evaluation).Dari uji coba yang dilakukan, tanggapan responden terhadap media pembelajaran mendapatkan nilai rata-rata 84\%. Validasi yang dilakukan oleh ahli media memperoleh nilai rata-rata sebesar 97\% sedangkan validasi ahli materi mendapatkan nilai rata-rata sebesar 74,8\%. Dan tanggapan pengguna memperoleh nilai rata-rata sebesar $80 \%$. Dengan demikian dapat disimpulkan dalam penelitian ini dinyatakan sangat layak sebagai media pembelajaran pada materi struktur kontrol perulangan. Sehingga dengan adanya media pembelajaran berbasis animasi dengan Adobe Flash cs6 ini diharapkan dapat menjadi inovasi untuk mendukung proses pembelajaran yang interaktif.
\end{abstract}

Kata Kunci : Media Pembelajaran, Animasi, Struktur Kontrol Perulangan, ADDIE

\section{PENDAHULUAN}

Dalam dunia pendidikan, dapat kita amati bahwa Teknik Informatika merupakan ilmu dan teknik yang membahas tentang pengolahan data atau masalah transformasi dengan memanfaatkan teknologi komputer melalui proses-proses logika. Pemrograman dasar merupakan salah satu mata pelajaran yang mempelajari tentang menyelesaikan pemecahan sebuah permasalahan menggunakan proses logika. Berdasarkan materi yang dikembangkan di dalam silabus, materi pembelajaran pemrograman dasar sebagian besar merupakan pembelajaran berbasis aplikasi. Materi didasarkan kepada pengenalan dan kemampuan peserta didik dalam menggunakan aplikasi di dalam komputer.

Kendala yang terjadi dalam proses pembelajaran diantaranya yaitu hambatan komunikasi. Dalam komunikasi sering timbul dan terjadi penyimpangan-penyimpangan sehingga komunikasi tersebut tidak efektif dan efisien, antara lain disebabkan oleh adanya ketidak siapan peserta didik, kurangnya minat dan kegairahan, dan sebagainya. Hambatan-hambatan yang ditemui dalam proses belajar-mengajar yang menyebabkan terjadinya ketidak lancaran komunikasi yang pertama yaitu

1. Verbalisme, dimana tenaga pendidik menerangkan materi pelajaran yang hanya melalui kata-kata atau secara lisan. Di sini yang aktif hanya tenaga pendidik, sedangkan peserta didik lebih banyak bersifat pasif, dan komunikasi bersifat satu arah.

2. Perhatian yang kurang dan bercabang, yaitu disebabkan dari prosedur dan metode pengajaran kurang bervariasi, sehingga penyampaian informasi yang "menoton" menyebabkan timbulnya kebosanan murid kemudian perhatian juga menjadi tidak terpusat pada informasi yang disampaikan dan bercabang perhatian lainnya. 
3. Tidak adanya tanggapan, yaitu tidak adanya merespon secara aktif apa yang disampaikan, sehingga tidak terbentuk sikap yang diperlukan. Yang terakhir yaitu Sikap pasif anak didik, yaitu tidak adanya gairah dalam mengikuti pelajaran disebabkan kesalahan memilih teknik komunikasi.

4. Kurangya media pembelajaran struktur kontrol perulangan

Berdasarkan hambatan di atas, tenaga pendidik dituntut harus mampu mempergunakan media khususnya media pembelajaran dalam proses belajar mengajar untuk memimalisir hambatan yang sering ditemui dalam proses pembelajaran. Dalam konsep teknologi pendidikan, tugas media bukan hanya sekedar mengkomunikasikan hubungan antara sumber (pengajaran) dan si penerima (peserta didik), namun lebih dari itu merupakan bagian yang integral dan saling mempunyai keterkaitan anatara komponen yang satu dengan yang lainnya, saling berinteraksi dan saling mempengaruhi. AECT (1986), mengemukakan bahwa komunikasi media (audio visual) telah mensintesiskan komponen-komponen dalam suatu sistem, dan rancangan sistem, serta konsep teori belajar [1].

Penggunaan media pembelajaran adalah sebuah cara yang digunakan oleh seorang tenaga pendidik untuk menyampaikan materi pelajaran kepada peserta didiknya agar dapat dengan mudah memahami materi yang akan disampaikan. Media pembelajaran juga membantu untuk menarik dan mengarahkan perhatian peserta didik untuk berkonsentrasi terhadap isi pelajaran yang berkaitan dengan makna visual yang ditampilkan atau menyertai teks materi pelajaran. Media Pembelajaran juga berfungsi untuk mempercepat proses belajar fungsi ini mengandung arti bahwa dengan media pembelajaran peserta didik dapat menangkap tujuan dan bahan ajar lebih mudah dan lebih cepat.

\section{MEDIA PEMBELAJARAN}

\section{Pengertian Media Pembelajaran}

Kata media berasal dari bahasa latin medius yang secara harfiah berarti 'tengah', 'perantara', atau'pengantar'. Secara lebih khusus, pengertian media dalam proses belajar mengajar cenderung diartikan sebagai alat-alat grafis, photografis, atau elektronik untuk menangkap, memproses, dan menyusun kembali informasi visual atau verbal. AECT (Association of Education and Communication Technology) memberi batasan tentang media sebagai segala bentuk dan saluran yang digunakan untuk menyampaikan pesan atau informasi. Disamping sebagai sistem penyampai atau pengantar, media yang sering diganti dengan kata mediator, dengan istilah mediator media menunjukkan fungsi atau perannya, yaitu mengatur hubungan yang efektif antara dua pihak utama dalam proses belajar, yaitu peserta didik dan isi pelajaran. Ringkasnya, media adalah alat yang menyampaikan atau mengantarkan pesan-pesan pengajaran [3].

Menurut Anderson dalam Bambang Warsita 2008, Media dapat dibagai dalam dua kategori, yaitu alat bantu pembelajaran (instructional aids) dan media pembelajaran (instructional media) [10]. Alat bantu pembelajaran atau alat untuk membantu tenaga pendidik dalam memperjelas materi (pesan) yang akan disampaikan. Oleh karena itu alat bantu pembelajaran disebut juga alat bantu mengajar (teaching aids). Misalnya OHP/OHT, film bingkai (slide) foto, peta, poster, grafik, flip chart, model benda sebenarnya dan sampai kepada lingkungan belajar yang dimanfaatkan untuk memperjelas materi pembelajaran.

Berikut ini merupakan penggolongan media : 


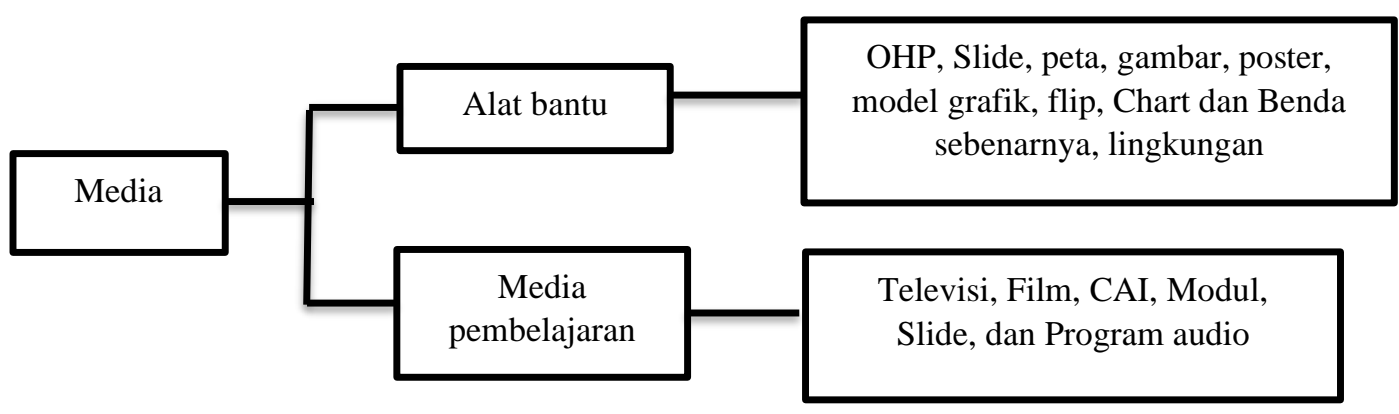

Gambar 1 Penggolongan Media [10]

\section{Fungsi dan Manfaat Media Pembelajaran}

Menurut Hamalik dalam Azhar Arsyad (2010: 15), mengemukakan bahwa pemakaian media pembelajaran dalam proses belajar mengajar dapat membangkitkan keinginan dan minat yang baru, membangkitkan motivasi dan rangsangan kegiatan belajar, dan membawa pengaruh-pengaruh psikologis terhadap peserta didik [3]. Penggunaan media pembelajaran pada orientasi pembelajaran akan sangat membantu keaktifan proses pembelajaran dan menyampaian pesan dan isi pelajaran pada saat itu. Selain membangkitkan motivasi dan minat peserta didik, media pembelajaran juga dapat membantu peserta didik meningkatkan pemahaman, menyajikan data dengan menarik dan terpercaya. Maksudnya: bahwasanya media pembelajaran paling besar pengaruhnya bagi indera dan lebih dapat menjamin pemahaman, orang yang mendengarkan saja tidak sama tingkat pemahamannya dan lamanya bertahan apa yang dipahaminya dibandingkan dengan mereka yang melihat, atau melihat dan mendengarkannya. Selanjutnya menjelaskan betapa pentingnya media pemebelajaran karena media pemebelajaran membawa dan membangkitkan rasa senang dan gembira bagi murid-murid dan memperbaharui semangat mereka, membantu memantapkan pengetahuan pada benak para peserta didik serta menghidupkan pelajaran.

Dalam proses belajar mengajar, fungsi media menurut Nana Sudjana dalam Hasrul [4][8] yakni :

a. Penggunaan media dalam proses belajar mengajar bukan merupakan fungsi tambahan, tetapi mempunyai fungsi sendiri sebagai alat bantu untuk mewujudkan situasi belajar mengajar yang efektif.

b. Penggunaan media pembelajaran merupakan bagian yang integral dari keseluruhan situasi mengajar. Ini berarti bahwa media pengajaran merupakan salah satu unsur yang harus dikembangkan oleh seorang pendidik.

c. Penggunaan media pembelajaran lebih diutamakan untuk mempercepat proses pembelajaran

Nana Sudjana dan Ahmad Rivai [9], mengemukakan manfaat media pembelajaran dalam proses belajar peserta didik yaitu:

a. Pembelajaran akan lebih menarik perhatian peserta didik sehingga dapat menumbuhkan motivasi belajar.

b. Bahan pembelajaran akan lebih jelas maknanya sehingga dapat lebih dipahami oleh peserta didik sehingga memungkinkannya menguasai dan mencapai tujuan pembelajaran.

c. Metode mengajar akan lebih bervariasi, tidak semata-mata komunikasi verbal melalui penuturan kata-kata oleh tenaga pendidik, sehingga peserta didik tidak bosan dan tenaga pendidik tidak kehabisan tenaga, apalagi bila tenaga pendidik mengajar pada setiap jam pelajaran. 
d. Peserta didik dapat lebih banyak melakukan kegiatan belajar sebab tidak hanya mendengarkan uraian tenaga pendidik, tetapi juga aktivitas lain seperti mengamati, melakukan mendemonstrasikan, memamerkan, dll.

Beberapa manfaat praktis dari penggunaan media pembelajaran di dalam proses belajar mengajar sebagai berikut:

a. Media pembelajaran dapat memperjelas penyajian pesan dan informasi sehingga dapat memperlancar dan meningkatkan proses dan hasil belajar.

b. Media pembelajaran dapat meningkatkan dan mengarahkan perhatian anak sehingga dapat menimbulkan motivasi belajar, interaksi lebih langsung antara peserta didik dan lingkungannya.

c. Media pembelajaran dapat mengatasi keterbatasan indera, ruang, dan waktu.

3. Prosedur Pemilihan Media

Menurut Rusman[7] Ada beberapa prinsip yang perlu di perhatiakan dalam pemilihan media pembelajaran meskipun caranya berbeda-beda. Namun demikian, ada hal yang seragam bahwa setiap media pembelajaran memiliki kelebihan dan kekurangan yang akan memberikan pengaruh kepada efektivitas program pembelajaran. Sejalan dengan hal ini, pendekatan yang ditempuh adalah mengkaji media pembelajaran sebagai bagian integral dalam proses pendidikan yang kajiannya akan sangat dipengaruhi oleh beberapa hal berikut :

a. Tujuan atau kompetensi apa yang akan dicapai dalam suatu kegiatan pembelajaran. Dari tujuan ini bisa dianalisis media apa yang cocok untuk mencapai tujuan tersebut.

b. Materi pembelajaran, yaitu bahan atau kajian apa yang akan diajarkan pada program pembelajaran tersebut

c. Familiaritas media dan karakteristik peserta didik/tenaga pendidik, yaitu mengkaji sifat-sifat dan ciri media yang akan digunakan

d. Adanya media yang bisa diperbandingkan karena pemilihan media pada dasarnya adalah proses pengambilan keputusan dari sejumlah media yang ada ataupun yang akan didesain atau dikembangkan.

Sementara itu, bila kita akan merancang atau mendesain media pembelajaran seharusnya melalui tiga tahapan yaitu:

a. Pembatasan, yaitu menyangkut rumusan tujuan atau kompetensi, rancangan media yang akan dikembangkan, beberapa persiapan awal dalam perencangan media yang menyangkut, kompetensi atau tujuan mater/konten, dana, dan aspek perencangan lainnya.

b. Pengembangan, dalam tahap ini sudah dimulai prosedur pembuatan media pembelajaran yang akan dikembangkan.

c. Evaluasi, yaitu tahap akhir untuk menilai media yang sudah dibuat, setelah melalui uji coba, revisi dan kajian dengan pihak lain.

Menyatakan sejumlah pertimbangan dalam memilih media pembelajaran yang tepat dapat menggunakan kata akronim kata Action, yaitu access, cost, technology, interactivity, organization, dan novelty.

a. Access,kemudahan akses menjadi pertimbangan pertama dalam memilih media.

b. Cost, biaya harus dipertimbangkan 
c. Technology Mungkin saja kita tertarik kepada satu media tertentu.

d. Intercitivity, media yang baik adalah yang dapat memunculkan komunikasi dua arah.

e. Organization, pertimbangan yang juga penting adalah dukungan organisasi.

f. Novelty, Kebaruan dari media yang anda pilih juga harus menjadi pertimbangan [7]

\section{ADOBE FLASH}

Adobe Flash (dahulu bernama Macromedia Flash) adalah salah satu perangkat lunak komputer yang merupakan produk unggulan Adobe Systems. Adobe Flash digunakan untuk membuat gambar vector maupun animasi gambar tersebut. Berkas yang dihasilkan dari perangkat lunak ini mempunyai file extension .swf dan dapat diputar di penjelajah web yang telah dipasangi Adobe Flash Player. Flash menggunakan bahasa pemrograman bernama ActionScript yang muncul pertama kalinya pada Flash 5.

Adobe Flash Professional CS6 merupakan versi Adobe Flash yang telah diperbarui dari versi sebelumnya yaitu Adobe Flash CS3 Professional, Adobe Flash CS4 Professional, dan Adobe Flash Professional CS5. Adobe Flash Professional CS6 adalah software grafis animasi yang dapat membuat objek grafis dan menganimasikannya sehingga kita dapat langsung membuat objek desain tanpa harus menggunakan software grafis pendukung seperti Ilustrator atau Photoshop [6].

Adobe Flash Professional CS6 merupakan software yang mampu menghasilkan presentasi, game, film, CD interaktif, maupun CD pembelajaran, serta untuk membuat situs web yang interaktif, menarik, dan dinamis. Adobe Flash Professional CS6 mampu melengkapi situs web dengan beberapa macam animasi, suara, animasi interaktif, dan lain-lain sehingga pengguna sambil mendengarkan penjelasan mereka dapat melihat gambar animasi, maupun membaca penjelasan dalam bentuk teks. Adobe Flash Professional CS6 sebagai software untuk pembuatan media pembelajaran interaktif berdasarkan pada beberapa kelebihan yang dimilikinya [2]. Adobe Flash Professional CS6 merupakan software yang dirancang untuk membuat animasi berbasis vector dengan hasil yang mempunyai ukuran kecil. Awalnya software ini diarahkan untuk membuat animasi atau aplikasi berbasis internet (online), namun dalam perkembangannya banyak digunakan untuk membuat animasi atau aplikasi yang bukan berbasis internet (offline). Dengan Action Script 3.0 yang dibawanya, Adobe Flash Professional CS6 dapat digunakan untuk mengembangkan game atau bahan ajar seperti kuis atau simulasi [5].

Adobe Flash Professional CS6 mempunyai kelebihan dibanding program lainnya yaitu pengguna dapat dengan mudah dan bebas dalam berkreasi membuat animasi dengan gerakan bebas sesuai dengan adegan animasi yang dikehendaki. Adobe Flash Professional CS6 menghasilkan file yang berukuran kecil, mampu menghasilkan file bertipe (ekstensi) FLA yang bersifat fleksibel, karena dapat dikonversi menjadi file bertipe swf, html, jpg, png, exe, mov [2]. Penggunaan Adobe Flash Professional CS6 untuk animasi atau pembuatan bahan ajar interaktif tidak sulit, karena tool-tool yang tersedia cukup mudah untuk digunakan, beberapa template dan componen juga sudah disediakan dan siap digunakan. 


\section{METODE PENELITIAN}

1. Tahap Analisis (Analysis)

Pada tahap ini yaitu menganalisa perlunya pengembangan media pembelajaran dan menganalisa kelayakan pengembangan media pembelajaran ini.

Berdasarkan tahap analisis yang dilakukan yang dilakukan peneliti dengan melakukan wawancara pada tanggal 29 November 2019, media pembelajaran yang digunakan tidak variatif yaitu masih menggunakan media cetak seperti buku teks dan lembar kerja peserta didik (LKS) sehinga membuat peserta didik menjadi kurang tertarik dan mengurangi minat belajar peserta didik saat pembelajaran berlangsung. Berdasarkan data yang diperoleh selanjutnya peneliti akan merancang media pembelajaran yang dapat meningkatkan minat belajar peserta didik agar lebih bersemangat saat pembelajaran berlangsung.

2. Tahap Desain (Design)

Desain media pembelajaran Struktur Kontrol Perulangan berbasis animasi Adobe Flash CS6 ini membutuhkan satu unit komputer/ laptop dan software animasi Adobe Flash CS6.

3. Tahap Pengembangan

Pada tahap pengembangan pembuatan produk dimulai sesuai dengan rancangan desain yang telah dibuat pada tahap sebelumnya yaitu tahap desain yang kemudian dikembangkan menjadi sebuah aplikasi media pembelajaran. Media pembelajaran yang telah dikembangkan ini berbasis animasi multimedia yag dibuat dengan menggunakan software Adobe Flash Cs6 yang berisi tentang materi struktur kontrol perulangan yang ditujukan untuk peserta didik kelas X jurusan RPL SMK. Pada media ini terdiri dari materi pembelajaran, soal-soal latihan atau quiz yang diharapkan dapat meningkatkan minat dan semangat belajar peserta didik. Pada tahap pengembangan dibutuhkan penilaian oleh ahli guna dilakukannya uji media pembelajaran ini adalah untuk mengumpulkan data yang akan menjadi bahan perbaikan terhadap produk yang telah dikembangkan. Perbaikan tersebut akan digunakan untuk memperbaiki produk agar lebih baik lagi sebelum media diuji coba oleh pengguna.

4. Implementasi

Pada tahap ini produk yang dihasilkan berupa aplikasi media pembelajaran yang diterapkan kepada peserta didik kelas X RPL1 SMKN Manonjaya yang berjumlah 20 orang.

5. Evaluasi

Tahap evaluasi merupakan tahap yang dilakukan untuk mengetahui tanggapan pengguna terhadap media pembelajaran yang dilakukan oleh peserta didik kelas X RPL1 SMKN Manonjaya yang berjumlah 20 orang.

Penilaian dalam tahap evaluasi ini berupa angket yang akan diisi penilaian oleh peserta didik. Didalam angket tersebut juga berisi saran dan kritik untuk perbaikan produk yang dibuat. 


\section{HASIL DAN PEMBAHASAN}

Pembuatan media pembelajaran Struktur Kontrol Perulangan animasi dengan berbasis Adobe Flash CS6 yang telah dilakukan dalam penelitian ini ditunjukkan dengan beberapa tampilan visualisasi gambar yang dapat dilihat secara langsung. Beberapa tampilan gambar utama dapat dilihat sebagai berikut.:

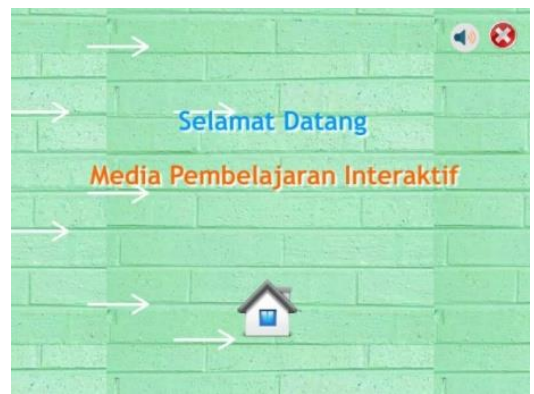

Gambar 2. Halaman Awal

Pada Gambar 2 merupakan tampilan awal pada media pembelajaran yang telah dibuat. Pada tampilan ini terdapat judul dari aplikasi yang dibuat, kemudian tombol home untuk memulai dari media pembelajaran ini menuju halaman selanjutnya. Menu sound berfungsi untuk mengatur suara on / off, menu close berfungsi untuk keluar dari apliksi media pembelajaran ini.

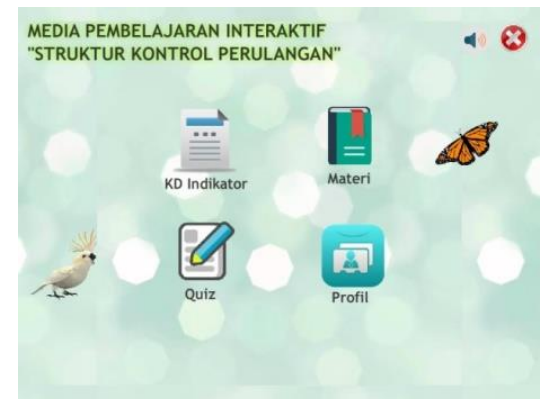

Gambar 3. Halaman Menu

Pada Gambar 3 merupakan halaman menu yang berisikan menu dari media pembelajaran yang dibuat. Pada media ini terdapat menu KD Indikator yang berisi Kompetensi Inti dan Kompetensi Dasar materi Struktur Kontrol Perulangan, menu materi yang berisikan materi pembelajaran, menu quiz berisi soal-soal latihan yang dapat dikerjakan oleh peserta didik dan menu profil. Menu sound berfungsi untuk mengatur suara on / off dan tombol close untuk keluar dari aplikasi media pembelajaran tersebut.

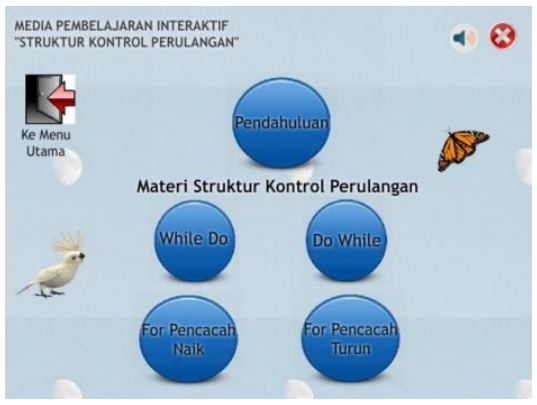

Gambar 4. Halaman materi

Pada Gambar 4 merupakan tampilan dari menu materi. Materi yang disajikan yaitu materi While Do, Do While, For pencacah naik, dan For pencacah turun terdapat tombol ke menu utama yang berfungsi untuk kembali kehalaman menu utama, menu sound untuk mengatur suara on / off dan tombol close digunakan untuk keluar dari aplikasi media pembelajaran ini. 


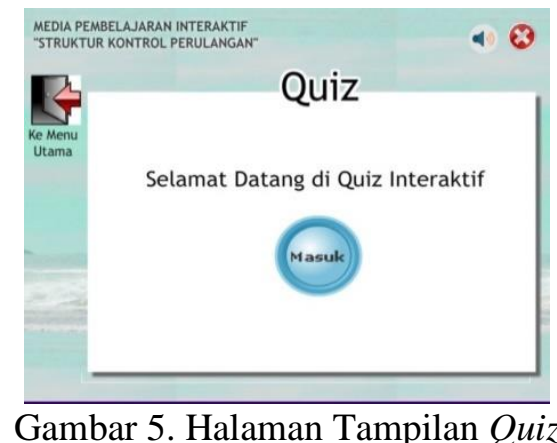

Gambar 5 merupakan tampilan dari halaman quiz yang terdapat soal-soal untuk latihan peserta didik dan juga terdapat score sebagai bentuk penghargaan peserta didik telah mengerjakan soal-soal tersebut, soal yang disajikan berupa pilihan ganda.Sistematika dari quiz adalah jika menjawab salah dan benar maka akan lanjut kehalaman atau soal selanjutnya. Terdapat tombol ke menu utma untuk kembali kehalaman menu utama, tombol sound untuk mengatur suara on/ off dan tombol close untuk keluar dari aplikasi media pembelajaran

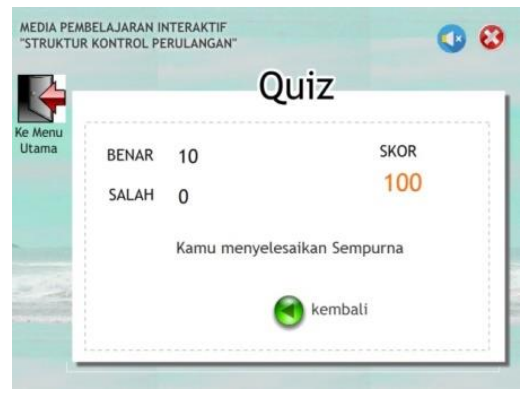

\section{Gambar 6. Halaman Tampilan Skor Quiz}

Gambar 6 merupakan tampilan dari halaman skor yang menampilkan jawaban yang benar dan yang salah, jumlah skor karena telah menjawab soal-soal dari quiz dan pernyataan jika telah menjawab semua soal. Pada tampilan ini terdapat tombol ke menu utama untuk kembali halaman menu utama, tombol menu untuk kembali ke halaman menu quiz, tombol sound untuk mengatur suara on/off dan tombol close untuk keluar dari aplikasi media pembelajaran.

\section{VALIDASI MEDIA PEMBELAJARAN}

Validasi media pembelajaran berbasis Adobe Flash CS6 diperlukan agar dapat mengetahui kelayakan media pembelajaran yang dikembangkan, proses kegiatan untuk media sebelum digunakan sebagai suatu media pembelajaran yaitu dilakukan penilaian oleh bapak dan ibu yang telah diberikan kepercayaan dalam memvalidasi desain media pembelajaran animasi berbasis Adobe Flash CS6. Pada tahap ini peneliti melakukan uji coba kepada ahli materi oleh Ibu Sulidar Fitri M.Sc., ahli media oleh Taofik Muhammad, S.Pd., M.Kom. Mereka adalah ahli dibidang media, ilmu pengetahuan, dan teknologi. 


\section{TANGGAPAN PENGGUNA TERHADAP MEDIA PEMBELAJARAN}

Pada bagian ini dilakukan pengujian media pembelajaran adalah dilakukan oleh peserta didik selaku subjek dalam penelitian dengan jumlah peserta didik 20 orang pada peserta didik pada kelas X RPL1 SMK Negeri Manonjaya. Sebagai hasil pembelajaran dalam penggunaan media pembelajaran berbasis multimedia interaktif pada tahap penilaian ini menggunakan tes. Tes dilakukan setelah melakukan pembelajaran dengan media pembelajaran animasi multimedia interaktif. Hasil penilaian selanjutnya dengan mengisi angket dengan rasio skor 1-4 yang diisi oleh peserta didik. Selanjutnya nilai tersebut dikonversikan untuk menjadi nilai kualitatif yang digunakan sebagai acuan penilaian kategori dan digunakannya tabel konversi nilai presentase. Adapun tabel konversi data menurut Sudjana (2005) sebagai berikut:

Tabel 1 Kriteria kelayakan oleh pengguna

\begin{tabular}{|c|c|}
\hline Presentase pencapaian & Interpretasi \\
\hline $81 \%-100 \%$ & Sangat Jelas \\
\hline $61 \%-80 \%$ & Jelas \\
\hline $41 \%-60 \%$ & Cukup jelas \\
\hline $21 \%-40 \%$ & Kurang jelas \\
\hline $1 \%-20 \%$ & Tidak jelas \\
\hline
\end{tabular}

Dari tabel 2 dapat dijabarkan bahwa skala $1 \%$ sampai $20 \%$ termasuk kedalam kategori tidak jelas, skala $21 \%$ sampai $40 \%$ termasuk dalam kategori kurang jelas, $41 \%$ sampai $60 \%$ termasuk kategori cukup jelas, skala $61 \%$ sampai $80 \%$ masuk dalam kategori jelas dan skala $81 \%$ sampai $100 \%$ termasuk dalam kategori sangat jelas.

Berikut ini merupakan tabel hasil uji kelayakan media pembelajaran oleh peserta didik aspek Desain dan Aspek Kemudahan Pengoperasian :

Tabel 2 Tabel Penilaian angket peserta didik

\begin{tabular}{|c|c|c|c|c|}
\hline No & Aspek Penilaian & Skor & Presentase & Kualitas \\
\hline 1 & Desain & 853 & $82 \%$ & Sangat Jelas \\
\hline 2 & Kemudahan Pengoperasian & 442 & $78,7 \%$ & Sangat Jelas \\
\hline \multicolumn{2}{r|}{ Total } & 643 & $80 \%$ & Sangat Jelas \\
\hline
\end{tabular}

Pada tabel 2 merupakan tabel penilaian angket peserta didik dimana nilai diambil dari 2 aspek yaitu aspek Desain dan kemudahan pengoperasian. Aspek Desain diambil dari soal nomor 1-13, dan aspek Kemudahan Pengoperasian diambil dari soal nomor 14-20. Nilai skor diperoleh dari jumlah nilai tiap peserta didik dalam satu kelas. Nilai total dari skor yaitu nilai dari kedua aspek dibagi 2 maka akan menghasilkan skor 643. Presentase diambil dari penilaian skor dibagi jumlah peserta didik yaitu 20. Total dari presentase diambil dari jumlah nilai presentase tiap aspek dibagi 4 maka akan menghasilkan 80\% yang dikategorikan sangat Jelas. Hasil penilaian tersebut kemudian disajikan kedalam diagram batang agar lebih mudah dalam membandingkan penilaian. 


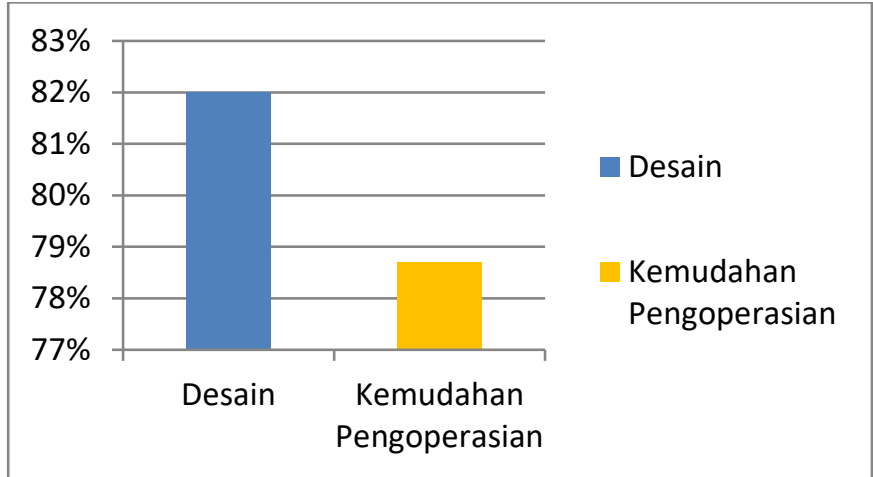

Gambar 7 : Diagram batang penilaian peserta didik

Berdasarkan gambar 7 dapat disimpulkan bahwa penilaian desain mendapatkan nilai paling tinggi diantara penilaian yang lainnya dengan presentasi $82 \%$.

\section{KESIMPULAN}

Berdasarkan pengembagan media pembelajaran berbasis animasi dalam materi struktur kontrol perulangan untuk peserta didik kelas X di SMK Negeri Manonjaya, dapat disimpulkan bahwa :

1. Media pembelajaran dikembangkan berbasis animasi dengan menggunakan aplikasi Adobe Flash cs6 materi struktur kontrol perulangan untuk peserta didik kelas X Sekolah Menengah Kejuruan.

2. Aplikasi media pembelajaran ini mendapat tanggapan sangat jelas dengan nilai presentase $80 \%$ dan dapat digunakan oleh pengguna untuk menunjang proses pembelajaran yang lebih interaktif juga dapat meningkatkan minat belajar peserta didik.

\section{DAFTAR PUSTAKA}

[1]. Anderson, R. H.. Selecting and developing media for instruction, Edisi Indonesia. Jakarta: Raja Grafindo Persada. 1994

[2]. Ariesto Hadi, Sutopo. Multimedia Interaktif dan Flash, Yogyakarta : PT Graha Ilmu. 2003

[3]. Azhar, Arsyad . Media Pembelajaran.Jakarta:PT.Raja Grafindo Persada. 2010

[4]. Hasrul. 2011. Desain Media Pembelajaran Animasi Berbasis Adobe Flash CS6 pada Mata Kuliah Instalasi Listrik 2. Jurnal MEDTEK. 3(2):1-8

[5]. Ikas Shofiani.(2012). Modul Pelatihan Pembuatan Media Pembelajaran menggunakan Adobe Flash CS3 Professional. Diakses dari https://ikashofiani.files.wordpress.com/2012/05/modul-pelatihan-adobe-flash-cs3profesional.pdf pada tanggal 15/09/2019 18.50 WIB

[6]. Island Script. Panduan Mudah Membuat Animasi, Jakarta:PT.TransMedia. 2008

[7]. Rusman. Manajemen Kurikulum, Jakarta Rajawali Pers. 2012

[8]. Sudjana, Nana. Penilaian Hasil Proses Belajar Mengajar. Bandung: Remaja Rosdakarya. 2002

[9]. Sudjana, Nana. Dasar-dasar Proses belajar mengajar. Bandung. Sinar Baru Algensindo. 2005

[10].Warsita, Bambang. Teknologi Pembelajaran: Landasan \& Aplikasinya, Jakarta: Rineka. 2008

\section{BIODATA PENULIS}

Anisa Rahmayanti adalah mahasiswa lulusan dari Universitas Muhammadiyah Tasikmalaya. Sarjana Program Studi Pendidikan Teknologi Informasi, Fakultas Keguruan dan Ilmu Pendidikan. Sekarang bekerja sebagai seorang guru 